Natalia Kućma

\title{
Logikomiks - filozofia i nauka w komiksie
}

Logikomiks jest opowieścią o poszukiwaniu przez Bertranda Russella absolutnej prawdy oraz o twórczych zmaganiach Apostolosa Doxiadisa, Christosa H. Papadimitriou (tekst), Alecosa Papadatos, Annie di Donna (rysunki) w trakcie pracy nad komiksem. W te dwie historie wpleciona jest jeszcze trzecia - Orysteia Ajschylosa, do której wystawienia przymierzają się przyjaciele autorów. Opowieść o Russellu przebiega dwutorowo: poznajemy go, gdy zmierza na uniwersytet wygłosić wykład, na którym będzie opowiadał o swoim dzieciństwie, młodości, aż dojdzie do bieżącej chwili, kiedy to stoi przed zgromadzonym tłumem i dyskutuje z nim. Struktura komiksu przypomina zatem rosyjską babuszkę, gdzie w jednej historii, kryje się następna.

Okładka komiksu nawiązuje do obrazu Roya Lichtensteina I can see the whole room... and there's nobody in it! Tym razem to jednak czytelnik jest podglądaczem, niczym przez dziurkę od klucza widzącym fragment sceny, w której sir Russell przewraca domino. Tak rozpoczyna się gra twórców z czytelnikiem, Russella z logiką, komiksu z filozofią i nauką. Celem tej pracy jest zbadanie czy komiks może być dziełem filozoficznym. Odpowiedź na to zagadnienie zwłaszcza na polskim gruncie nie jest oczywista, bo choć praca greckich twórców ukazała się w 2011 roku (wydanie oryginalne 2009) i nie jest jedynym wybitnym dziełem, jakie ukazało się na polskim rynku ${ }^{1}$ to

1 Za sam rok 2011 można wymienić: Mglisty Billy Bianco, Berlin. Miasto dymu Lutesa, Pinokio Winshlussa, Pluto autorstwa Tezuki i Urasawy, oraz Ikigami autorstwa Mase. 
w wielu głowach wciąż pokutuje mit o komiksie jako prostej rozrywce dla mało wymagających czytelników. Z jednej strony jest to spadek po epoce PRL'u, gdzie rzeczywiście najwięcej wychodziło prac bardzo prostych, skierowanych do młodego czytelnika oraz takich, w których dominował przekaz propagandowy (sztandarowe przykłady to serie Tytus, Romek i A'Tomek Henryka Jerzego Chmielewskiego oraz Kapitan Żbik różnych autorów). Dla szerszej publiczności przełomowym momentem było wydanie Mausa Arta Spiegelmana (wyd. Post 2001), które uświadomiło wielu czytelnikom, wzbudzając jednocześnie wiele kontrowersji, że komiks jest także dobrym narzędziem do opowiadania o sprawach trudnych. Drugi powód lekceważenia komiksu może leżeć w samej genezie słowa „komiks” pochodzącego „z ang. comic strip, gdzie pierwszy człon poświadcza humorystyczny charakter opowiastki, a drugi formę jej podania w postaci zestawionych obok siebie obrazków (tworzących pasek)" [Szyłak 2013: 147]. Nazwa ta szybko przestała być adekwatna do zjawiska, które tendencyjnie oddzielano od „naturalnie” poważniejszych książek. Z tego stereotypu wywodzi się też termin „powieść graficzna” (graphic novel), który ma na celu oddzielenie niepoważnych komiksów od poważnych historii opowiedzianych obrazem, i który odbierany jest często jako coś odrębnego od komiksu, gdy tymczasem, według Jerzego Szyłaka i Janusza Dunina jest jego podkategorią obok krótkiej formy i cyklu [Szyłak 2013: 150]. Ta „nobilitacja” samym twórcom nie zawsze wydaje się potrzebna, a autorzy jak Marjane Satrapi, Art Spiegelman, czy autorzy Logikomiksu Apostolos Doxiadis, Christos H. Papadimitriou (tekst), Alecos Papadatos, Annie di Donna (rysunki) mówią o swoich pracach, że są komiksami ${ }^{2}$. Użycie tego słowa pozwoliło zresztą greckim autorom, na udaną grę słowną zamieszczoną w tytule. Logikomiks mieści w sobie zarówno logikę, logos, log (jako skrót od słowa logarytm) oraz miks (czyli mieszanie, pomieszanie).

2 Choć z drugiej strony w posłowiu naświetlając motywy i intencje powstania dzieła piszą, iż nie chcieli stworzyć książki historycznej, a powieść graficzną [Logikomiks 2013: 315] 
Głównym wyznacznikiem dzieła filozoficznego, wedle Hanny Rosnerowej jest język, w którym „ekspresja myśli filozoficznej jest samą tą myślą" [Rosnerowa 1975: 36], innymi słowy możność sformułowania myśli i sam ten proces są ze sobą tożsame. Filozofowie poruszający się w języku dążą do jak najściślejszego, najpoprawniejszego wyrażenia się (nawet, wtedy gdy, a może przede wszystkim, wtedy gdy, twierdzą, że język nie jest w stanie oddać myśli). Warto jednak zauważyć, że każdy szuka nie tylko najodpowiedniejszych słów, ale i formy; dla Platona była to forma dialogu, dla św. Augustyna wyznania i rodzaj pamiętnika, dla Woltera powiastka filozoficzna, dla Spinozy traktat, aforyzmy dla Nietzschego i Ciorana, dla Sartre'a i Camusa także powieści, opowiadania i sztuki teatralne. Wachlarz możliwości, z których korzystali myśliciele na przestrzeni czasu jest niezwykle szeroki i nie daje się sprowadzić do sztuki jednej narracji, czy jednorodnego stylu wypowiedzi. Narodziny komiksu pod koniec XIX wieku dostarczyły otwartym umysłom jeszcze jednego narzędzia do obrazowania idei. Apostolos Doxiadis już na samym początku informuje czytelnika, że jakkolwiek by nie próbował podchodzić do swojej pracy musi pamiętać, że ma do czynienia przede wszystkim z opowieścia o ideach, o ludziach, o namiętności [Logikomiks 2011: 12, 98]. Ludzie zaś od niepamiętnych czasów opowiadają sobie historie by się zabawić, pouczyć, pocieszyć. Na swój sposób, choć w innych proporcjach postępuje filozofia odkrywając prawdę o człowieku i świecie, niosąc pocieszenie, pogłębiając zdziwienie, a czasem rozśmieszając i dostarczając rozrywki w towarzyskich kręgach.

Ideą przewodnią Logikomiksu jest dość przewrotna hipoteza, iż logika wyplywa z szaleństwa. Apostolosa, Christosa, Alecosa i Annie intrygują losy najwybitniejszych umysłów logiczno-matematycznego świata XX wieku. Inspiracją jest dla nich również artykuł Gian-Carla Roty'ego, w którym porusza on problem zastanawiająco wysokiego odsetka psychoz wśród największych twórców logiki. Podążając za tą myślą, autorzy wstępnie zakładają, iż oddanie się logice zwiastuje rezygnację ze zdrowia psychicznego, choć nie tylko. Jak przewrotnie zresztą zauważa Russell w pierwszych słowach swojego wykładu: „Pan dziekan prosił mnie o prelekcję na temat roli logiki w życiu człowieka. Oczywiście, gdybym 
potraktował jego prośbę dosłownie... usłyszeliby państwo najkrótszy wykład w dziejach!” [Logikomiks 2011: 31].

Wiele decyzji staramy się podejmować posługując się rozumem, czyli w sposób racjonalny, ludzkie działania często cechuje irracjonalizm. Russell, widząc w emocjach instynkt niepoddający się woli rozumu, a więc szkodliwy, próbował je zwalczyć. To niezrozumienie ludzkiej natury przysporzyło mu wielu kłopotów w życiu rodzinnym. Sam nie mając problemów z trzymaniem się narzuconych sobie reguł, wymagał tego także od swojego otoczenia. Ta nieharmonijność między rozumem a emocjami (rozumianymi jako irracjonalne, bo nie podlegające kontroli), albo szerzej między rozumem a ludzkim światem, stanowi główną oś zainteresowania greckich twórców. W komiksowej wymianie listów między Doxiadisem a Papadimitriou, kształtuje się ich definicja obłędu. Logicy byli ludźmi doskonale tworzącymi udane mapy, algorytmy, wzory i przepisy, byli wyśmienitymi teoretykami, ale ich tragedia polegała na tym, że myśleli, że można je zastosować do życia. Ścisłe, precyzyjne, naukowe metody nie przystają do dynamicznej egzystencji. Dlatego też greccy autorzy dramat życia Russella konfrontują z grecką tragedią, Oresteią Ajschylosa, której zakończenie (a jednocześnie zakończenie komiksu) scala wyrozumową mądrość Ateny z namiętnością Erynii. Bowiem natura życia jest taka, że potrzebuje obu by zaistniała harmonia zarówno dla pojedynczej jednostki, jak i dla całego społeczeństwa.

Komiksowi temu, warto się przyjrzeć od strony wizualnej. Większość kadrów jest prostokątna, z wyraźnie zakreślonymi granicami, co $\mathrm{z}$ jednej strony oddaje russellowską potrzebę porządku, $\mathrm{z}$ drugiej poprzez kontrast podkreśla całostronicowe plansze - jak ta na stronach 202-203 - w której autorzy rezygnują ze ściśle wyodrębnionych kadrów na rzecz oddania spontanicznej i niekontrolowanej dyskusji, jaką prowadzili podczas spaceru. Postacie i przedmioty otoczone są dokładnym konturem, a kolory są czyste. Nie jest to konwencja realistyczna, ale właśnie „russellowska”: jasna, uproszczona i dokładna. W komiksie nie ma zbędnych elementów ani przerostu szczegółów. Liternictwo również jest szlachetnie proste, a ważniejsze słowa, czy wyróżnienia odznaczają się pogrubieniem lub kursywą (bądź oboma 
naraz). Ponadto dzieło to nawiązuje do prac malarskich (na przykład: do Wędrowca nad morzem mgły Caspara Davida Friedricha [Logikomiks 2011: 85], gdzie młody Russell daje się uwieść potędze przyrody, czy Krzyku Edvarda Muncha [Logikomiks 2011: 234]; oraz pełne licznych literackich odniesień, wyrażonych już bardziej explicite (młody Russell i Alys czytający Alicję w Krainie Czarów [Logikomiks 2011: 102], nawiązanie do Doktora Jekylla i Pana Hyde'a [Logikomiks 2011: 231]).

Opowieści o autoreferencyjności (prowadzone równolegle przez Russella na wykładzie i przez autorów między sobą) [Logikomiks 2011: 164-167] są tymi momentami w komiksie, w których najbardziej widać dydaktyczny zamysł dzieła. Czytelnik nieobeznany z filozoficznymi paradoksami utożsamia się z Annie, która zadaje podstawowe pytania i prowadzi rozumowanie, niczym grzeczna uczennica podążająca za kolejnymi wskazówkami nauczyciela. Rozważania o autoreferencyjności wpasowują się także w wątek metatekstowych rozmyślań Apostolosa Doxiadisa i Christosa H. Papadimitriou dotyczących budowy i rozwoju ich pracy. Jak widać w dialogu między Christosem a Apostolsem wątpliwości budziła sama komiksowa forma. Apostolos: To idealna forma dla opowieści o bohaterach dążących do osiągnięcia wielkich celów!", na co Christos ironizuje: "Jasne! Od Kaczora Donalda, przez Supermana, do Bertranda Russella!" [Logikomiks 2011: 22]. A to właśnie fascynująca postać logika jest głównym powodem powstania historii. Bertrand Russell - złożona osobowość, wszechstronnie działając na polach nauki, polityki, edukacji, jest dla autorów postacią namiętną, zarówno w życiu osobistym, jak i zawodowym - będąc jednocześnie doskonałym przykładem bohatera. Bohatera w bardzo greckim stylu - pełnym pragnień i niepewności, co dobrze uzmysławia zestawienie ze scenami z teatru.

Jak pisał Joseph Campbell: „Bohater to człowiek, który dał swoje życie za coś większego od siebie” [Campbell 1993: 196], to ktoś, kogo działania wykraczają poza obszar normalnych ludzkich dokonań. Jest więc Russell nie tylko historyczną postacią, ale i bohaterem par excellence - przemierzającym niebezpieczne obszary, z których może przynieść innym prawdę, choć musi za nią zapłacić niemałą cenę. Komiks to niejako „naturalne” miejsce występowania superbohaterów, a także 
wyzwanie polegające na przełożeniu języka filozofii na język wizualny. Jak pisała Hanna Rosnerowa przekład ma wartość samą w sobie, ponieważ jest zabiegiem twórczym: „prowadzi niejednokrotnie do wydobycia różnych problemów, które by inaczej w ogóle nie powstały; jego funkcja jest specyficzna nie ogranicza się więc do podniesienia stopnia zrozumiałości tekstu i do przystosowania własnego języka do potrzeb określonej filozofii” [Rosnerowa 1975: 37]. Oczywiście w przytoczonym fragmencie autorka ma na myśli problemy związane z przekładem z języka obcego na język rodzimy ${ }^{3}$, lecz poczynione przez nią obserwacje można odnieść i do szerzej pojętego przekładu. Przekładu albo tłumaczenia, przekład bowiem odnosi się do prostej nieraz czynności przeniesienia czegoś w inne miejsce, tłumaczenie zaś jest również wyjaśnianiem, swoistą interpretacją. Logikomiks konwencjonalne symbole logiczne zastępuje konwencjonalnymi znakami komiksowymi, co widać na przykładzie Annie myślącej siebie, myślącej siebie... [Logikomiks 2011: 167] w prosty i dokładny sposób oddaje paradoks odkryty przez Russella. Jak wspominałam na samym początku, filozofowie upodobali sobie różne formy wyrażania gnębiących ich zagadnień. Russell wyraził swój paradoks językiem matematyki, ale i stworzył fabularyzowaną jego wersję. Kazał wyobrazić sobie, iż mieszkańcy pewnego miasta muszą co dzień być ogoleni. Fryzjer goli tych, którzy nie golą się sami. Czy fryzjer goli się sam? Jeżeli jest fryzjerem, to znaczy, że goli tylko tych, którzy nie golą się sami. Jeśli zaś goli się sam, to znaczy, że nie jest fryzjerem. Na marginesie warto dodać, że twórcy komiksu zilustrowali tą historię w stylu czarno-białych wczesnych prac Walta Disneya - co nadaje jej uroku patyny oraz paradoksalnie lekkości i humoru, mimo iż sam paradoks brutalnie zburzył dotychczasowe podstawy matematyki. Problem autoreferencyjności, komplikujący wiele naukowych zagadnień, nie jest jednak siłą niszczycielską dla sztuki. Jeśli wypowiedź naukowa odnosi się do samej siebie, może być to źródłem paradoksów. Dla sztuki jednakże opowiadanie o samej o sobie bywa raczej bodźcem

${ }^{3}$ Swoją drogą to też jest interesujące, że w komiksie warstwa słowna podlega tłumaczeniu (z języka greckiego na język polski) ale wizualna już nie. 
do refleksji i samopoznania. Zwracanie się wprost do czytelnika oraz rozważanie sensowności dzieła w ramach tego dzieła nie jest zabiegiem nowym, jednakże Logikomiks ukazuje problem z nowej perspektywy.

Matematyka, logika, filozofia, komiks... mnogość dziedzin obecnych w jednym dziele może prowokować pytanie o potencjalnego odbiorcę tej pracy. Przy rysowaniu spotkania Russella z Moorem pojawia się dyskusja, w której Christos, z zawodu informatyk, wyraża wątpliwości czy używanie pojęcia „tautologia” nie jest zbyt techniczne. „Wiem co to jest tautologia! Ale czy przeciętny czytelnik o tym wie?”, na co Apostolos ripostuje: „A istnieje ktoś taki?” [Logikomiks 2011: 97]. Według Umberto Eco „tekst jest mechanizmem, który ma za zadanie wytworzyć swego czytelnika modelowego" [Eco 2008: 72], zatem każdy twórca zakłada sobie jakiegoś Czytelnika Modelowego. Dla autorów Logikomiksu jest nim osoba inteligentna, wykształcona, ale niekoniecznie związana z matematyczno-logicznym światem. By uczynić swój wykład dla niej przystępnym, wprowadzają do opowieści ludzi niezorientowanych w logicznych zawiłościach, z którymi niewykształcony w tej dziedzinie czytelnik może się utożsamiać: rolę tę pełnią twórcy komiksu Annie, Anne i Alecos, a w historii Russella jego żona Alys. Ich pytania i okrzyki przerywają nazbyt techniczne fragmenty historii i w prostszy sposób tłumaczą zawiłości omawianych zagadnień. Napięcie między Apostolosem a Christosem dotyczące ich pracy i potencjalnego odbiorcy, jest wynikiem niezdecydowania czy poprowadzić komiks bardziej w stronę „logiki dla opornych” czy „tragedii z logikami w roli bohaterów”. Ponieważ ostatecznie komiks idzie trochę w każdą stronę, jest on książką „dla wszystkich i dla nikogo" i fan Supermana i filozof (pomijając przypadek, miłośnika Supermana zajmującego się również filozofią) będą usatysfakcjonowani obcowaniem $\mathrm{z}$ tą historią.

Jak wiadomo praca naukowa musi spełniać pewne określone wymogi formalne. $\mathrm{Z}$ tej perspektywy warto przyjrzeć się strukturze Logikomiksu. Składa się on z zatytułowanych rozdziałów, z których trzy nawiązują nazewnictwem do przedstawienia teatralnego czy opery: uwertura, antrakt, finał. Sama książka zaś posiada jeszcze uwagi od autorów dotyczące ich metodologii, założeń, co więcej ma nawet 
bibliografię, źródła cytatów oraz alfabetyczny zbiór encyklopedycznych notek o poszczególnych uczonych lub wyjaśnienia terminów. Ponadto sami artyści niczym dobrzy scholastycy formułują tezę, próbują jej dowieść, argumentują nad różnymi opcjami. A także powołują się na pewne prawa (licentia comixica). Są to bez wątpienia elementy pracy naukowej, choć tu mają raczej wymiar popularno-naukowy: notatka o Arystotelesie będzie przydatna temu wariantowi Czytelnika Modelowego, dla którego tematy tutaj poruszane są nowe. Choć można spojrzeć na nie z jeszcze innej strony - jako świadectwo pewnej sumienności. W pewnym momencie akcji czytelnik dowiaduje się, że sir Russell miał brata [Logikomiks 2011: 77] lecz jego osoba została przez autorów celowo pominięta. „Licentia comixica” mówi Annie di Donna. Przemilczenie pewnych wydarzeń, przerysowanie innych, dodanie nowych - wszystko po to by stworzyć własną postać, a jednocześnie oddać coś z ducha pierwowzoru. W takim wypadku pojawia się pytanie czy takie żonglowanie faktami przystoi pracy, która ma w podtytule słowo „prawda”, i która jest po części stylizowana na rozprawę naukową. Twórcy Logikomiksu skrupulatnie zbierali i badali cały dostępny im materiał empiryczny mając jednocześnie w pamięci słowa malarza El Greco o potrzebie swobody artystycznej wypowiedzi. Pewne przesunięcia i zmiany proporcji są $\mathrm{w}$ istocie formalnymi zabiegami, które służą lepszemu wydobyciu tego, co najważniejsze. Dla przykładu oddanie prawdy o walce egzystencjalnej, fizycznej, emocjonalnej nie zostaje umniejszone przez dodanie epizodu ze spotkania Russella z Gottlobem Frege, które twórcy umiejscawiają w kilka lat po faktycznej śmierci tego drugiego. Podobnie zresztą postąpił Søren Kierkegaard pisząc swoje opowieści o Abrahamie. Abraham duńskiego filozofa nie jest postacią historyczną czy biblijną, ale pretekstem do głębszych rozważań nad wiarą. Z listów, pism, anegdot i wspomnień wyłania się obraz Bertranda Russella jako osoby dowcipnej, stanowczej, namiętnej, tytana pracy - i taki też jest jego obraz w Logikomiksie.

${ }^{4}$ Logikomiks. W poszukiwaniu prawdy - tak brzmi pelny tytuł wydania polskiego, angielskiego natomiast: Logicomix. An Epic Search for Truth. Zaś w stopce redakcyjnej jako tytuł oryginału podaje się po prostu Logicomix. 
Konflikty między logikami ukazane w komiksie pokazują, z jaką namiętnością podchodzili do swojej pracy ludzie, którzy nade wszystko wsławiali potęgę rozumu. A przy tym kłótnie na Kongresie w Paryżu [Logikomiks 2011: 147 in.], reakcje na wieść o paradoksie Russella [Logikomiks 2011: 168 in.] są mimo calej powagi jednymi z weselszych fragmentów w komiksie. Dla Christosa finałem całej historii jest wynalezienie komputera, maszyny, której nie można posądzać o szaleństwo. A obłęd rzeczywiście czai się w tle życia bohaterów. W domu Russellów zdarzały się przypadki obłędu, które cieniem strachu kładły się na całym życiu filozofa. Także inni wielcy uczeni popadli w obłęd lub mieli do czynienia z osobami chorymi: David Hilbert wyrzekł się chorego syna, którego zamknięto w zakładzie; Kurt Gödel zagłodził się w depresji i paranoi, że wszyscy chcą go otruć; Moritza Schlicka zastrzelił chory psychicznie student, wyznawca Adolfa Hitlera; Georg Cantor na starość zają̨ się udowadnianiem, że Jezus był naturalnym synem Józefa z Arymateii; a Gottlob Frege pisaniem wściekle antysemickich tekstów o żydowskim spisku; Ludwig Wittgenstein zaś miał, delikatnie mówiąc, trudny charakter. A mimo to, greckim twórcom nie udaje się obronić tezy o związku szaleństwa z logiką. Bertrandt Russell kończy swój wykład apelem do publiczności o rozwagę i przestrzega przed stosowaniem zastyglych formul do ludzkiego życia.

Podsumowując chciałabym podkreślić, że Logikomiks jest komiksem filozoficznym. „Matematyka i komiks są jak oliwa i woda... Nigdy się nie mieszają!" [Logikomiks 2011: 200] wykrzykuje w pewnym momencie Apostolos Doxiadis. Jednak całe dzieło jest zaprzeczeniem tych słów. Zresztą wpisuje się w dobrą tradycję łączenia dzieła sztuki $\mathrm{z}$ dziełem inspirowanym nauką. Choć Alicja w Krainie Czarów Lewisa Carrolla komiksem nie jest, nie otrzymałaby zapewne swego kształtu, gdyby jej twórca nie był matematykiem i logikiem lubującym się w kryptografii i zagadkach, bardzo ceniącym sobie dorobek Boole'a. Z czasów nieśmiało rozkwitającej miłości między Bertiem a Alys, pojawia się scena, w której oboje siedzą pod drzewem i czytają. Ona czyta Alicję w krainie czarów Lewisa Carrolla, on - Prawa myślenia George'a Boole'a [Logikomiks 2011: 101], obydwoje zaś robią to na kartach pracy, która jest, jaka jest, bo może taka być, albowiem „przeciwnie 
wprost, gdyby tak było, mogłoby tak być, a gdyby mogło tak być, byłoby tak; a, ponieważ nie jest, nie jest. To logiczne" [Lewis Carroll za: Logikomiks 2011: 102].

\section{Bibliografia}

Eco U. [2008], Interpretacja i historia, [w: Interpretacja i nadinterpretacja, Collini S. (red.), Kraków.

Eco U. [2008], Superman $w$ literaturze masowej. Powieść popularna: między retoryka a ideologia, Ugniewska J. (przeł.), Wydawnictwo Znak, Kraków.

Eco U. [2010], Apokaliptycy i dostosowani. Komunikacja masowa a teorie komunikacji masowej, Salwa P. (przeł.), Wydawnictwo WAB, Warszawa.

Carroll N. [2011], Filozofia sztuki masowej, Przylipiak M. (przeł.), Wydawnictwo Słowo/Obraz Terytoria, Gdańsk.

Carroll L. http://pl.wikipedia.org/wiki/Lewis_Carroll data dostępu 2012.

Campbell J. [1994], Potega mitu. Rozmowy Billa Moyersa z Josephem Campbellem, Kania I. (przel.), Wydawnictwo Znak, Kraków.

Hempoliński M. [1983], Bertrand Russell - analiza formalna przeciwko paradoksom filozofii, [w:] Filozofia wspótczesna, tom 2, Kuderowicz Z. (red.), Wydawnictwo Wiedza Powszechna, Warszawa.

Doxiadis A., Papadimitriou C. H., Papadatos A., di Donna A. [2011], Logikomiks. W poszukiwaniu prawdy, Mikos J. (przeł.), Wydawnictwo WAB, Warszawa.

Mann G. [1996], Bertrand Russell, Paczkowska-Łagowska E. (przeł.), „Kwartalnik Filozoficzny”, t. XXIV, s. 175-206.

Mc Cloud S. [1994], Understanding Comics: The Invisible Art, Harper Perennial, New York.

Rosnerowa H. [1975], Jedność filozofii i wielość języków. O filozoficznym przekładzie i jego funkcji poznawczej, Instytut Wydawniczy PAX, Warszawa.

Russell B. [1996], Autobiografia 1872-1914, Zieliński B. (przeł.), Wydawnictwo Czytelnik, Warszawa.

Szyłak J. [2013] Komiks w szponach miernoty. Rozprawy i szkice, Wydawnictwo Timof i cisi wspólnicy, Warszawa. 